\title{
On the possible relationship between the Matsushiro earthquake swarm and the inactivity of Asama-yama Volcano (*)
}

\author{
P. HÉDERÝ́RI (**) \\ Received on October 30 th, 1975
}

\begin{abstract}
Summar. - During the famous Matsushiro cartluquake swarm more than 700000 (voleanic) earthquakes were observed. At the same time remarkable contortion of the ground also took place together with other strange geophysical phenomena. In the course of these events, voleano Asamil-yama (one of the most active voleanoes of the world) showed a perfect inactivity. This voleano is situated at a clistance of about $30 \mathrm{~km}$ measured from Matsushiro, that is very near the site of the events. In the paper a causal relationship is suggested between the geophysieal phenomena at Matsushiro and the inactivity of Asama-yana. Two alternative possibilites are treated briefly. The hypothetical character of these ideas is strongly emphasized by the author, however both possibilities appear to be pliysically real and can explain all the inportant geophysical events observed on the spot.

Riassunto. - Durante il famoso terremoto di Matsushiro furono registrate piu di 700.000 microscosse a carattere vuleanico. Contemporaneamente furono notati e ma notevole torsione del terreno e altri strani fenomeni geofisici. Nel corso di tali eventi il vuleano Asama-yama (uno dei più attivi del mondo) si mostrò del tutto inativo; questo vulcano è a circa $30 \mathrm{~km}$ da Matsushiro, vicinissimo al luogo dove occorsero gri eventi.
\end{abstract}

(*) One of the hypotheses, discussed in this paper, was presented on Symposimm No. 5. (Recent Crustal Movements) on the General Assembly of IIGG, Grenoble, Franee, 1975 . The original version of the paper was received on $A$ usust 14 th, 1975; revised version on Oetober $30 t h 1975$.

(**) Research Group on Planetary and Geoplyysical Volcanologry, (Working Group of International Association of Planetology), II. 1023, Budapest, I1. Arpád fejelelem ùtja 40-41. Hungary. Contribution 0:j75j RiGl'il. 
Nella nota viene proposta una relazione casuale tra i fenomeni geofisiei di Matsushiro e l"inattivita del vulcano Asama-yama. In breve sono state trattate due possibili alternative.

Il carattere puramente ipotetico di tali idee è messo bene in evidenza dall Autore: tuttavia entrambe le ipotesi potrebbero avere un reale significato fisico e spiegare, quindi, tutti quegli importanti eventi geofisici osservati in loco.

\section{INTRODUCTION}

The earthquake swarm of voleanic shooks, that commenced on the 3rd August, 1965 and ended in October, 1967, at the near proximity of Matsushiro (Nagano Prefecture, Honshu, Japan) is really unique in the history of geophysical volcanology, due to the very great number of the shocks. The exceptionally long series of the quakes were accompanied by landslides, the creation or activization of a strike-slip fault, fracturing of the ground, changes in the local geomagnetic and gravity fields, outflow of a remarkable amount of ground-water and last, but not least, crustal deformations.

In the present paper a new interpretation of these unprecendented series of events is presented. The basis of this new explanation is an empirical fact: namely the strange inactivity of the Asama-yama volcano. We should like, however, to emphasize very strongly the hypothetical character of this solution which - as a matter of fact - comprises two alternative possibilities.

The center of the epicentral area of the swarm is to be found near an extinct volcano, called Minakami-yama, at a distance of about $30 \mathrm{~km}$ northwest of Asama-yama, the latter being one of the most active voleanoes of the world. Until the end of the swarm about seven hundred thousand stronger and weaker shocks (of volcanic origin) occurred (Kasahara, 1970) $\left(^{\circ}\right)$ and many of them were observed directly by the inhabitants of the affected region. Only very few shocks reached a Richter-magnitude of 5.0 or over it. The total energy, released during the swarm as a whole corresponded approximately to the energy of a single earthquake of a magnitude of $M=6.3$. Within the series three very active seismic periods can be distinguished. The first climax took place in November, 1965; the second in March and $\Lambda$ pril, 1966; the third in A I gust and september of the same year. The third eulmination was associated with landslides and the outflow of a lavge amount of ground-water (Hagiwara and Iwata, 1968) $\left({ }^{2}\right)$. Generally, however 
mostly during the first part of the activity, the hypocentral region of the felt shocks showed a concentration between the depth of 2 and 8 $\mathrm{km}$ with a center at about $5 \mathrm{~km}$. The maximum horizontal extent of the epicentral region measured about $34 \cdot 18 \mathrm{~km}$.

The crustal deformations were similarly very remarkable and had been in close association with the seismicity. Kasaliara, $1970\left(^{6}\right)$, presented an interesting graph on the temporal variation of the cumulative seismic energy, the upheaval of the Minakami-yama region, the exten-

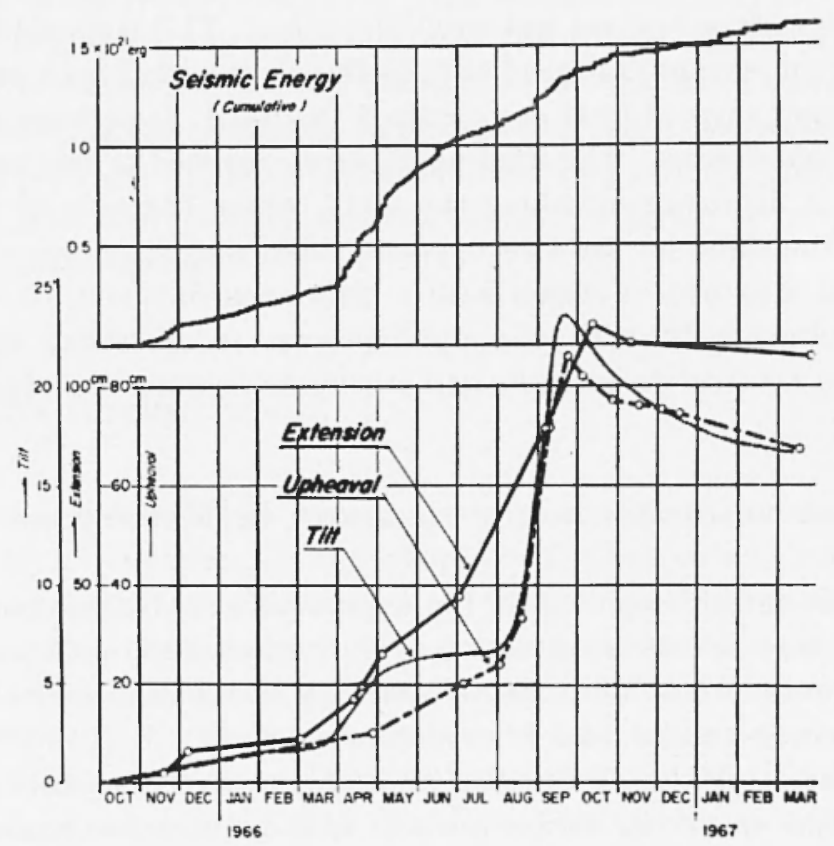

Fig. 1. - Development of various sorts of crustal deformations at the Mat sushiro area, compared with seismic energy release (after the Bulletin of the Earthquake Researeh Institute).

sion of the base-line between village Sorobeku and the extinct volano, Minaliami-yama, as well as the tilt of the ground (Fig. 1). The uplift amounted to about 90 centimeters, the maximum extension was around or somewhat greater than 116 centimeters and the tilt reached almost 25 seconds of arc. The rate of these crustal deformations showed remarkable changes in April, 1966 and in September, the same year, corresponding well to the second and third culminations of the seismic 
activity. After the September-October perior of 1966 , the deformations exhibited an abrupt reversal-process (Kasahara et al., 1968) (5).

The existence of a strilie-slip fault of the left-lateral type, between Minakami-yama and Sorobeku is suggested by Kasahara. The length of this (supposedly buried) fault is $7 \mathrm{~km}$ and its vertical extent may be $3 \mathrm{~km}$.

The trend of the fault is roughly northwest-southeast. The strikeslip displacement along this fault duning the swarm amounted to almost 2 metres. The fault runs across the northern slope of Minakami-yama where the most prominent upheaval took place. This appears to be an especially important empirical fact, as this volcano has been considered to be extinct since at least one hundred thousand, or perhaps five hundred thousand years. The local uplift here consister of two main components: a displacement along the fault, where the rate of upheaval was not the same on the two opposite silles, and a doming-up of the epicentral area over a region with a climension of about $10 \cdot 10 \mathrm{~km}$.

Simultaneously with the uplift-process in question, significant changes in the local geomagnetic and gravity fields were also experiencerl.

\section{1. - THE Volcanoes in THE PRoximity OF Matsusiiro}

In the anthor's opinion for the explanation of all these phenomena it is necessary to eall the attention to the curious and by all probability very important fact that the neighbouring voleanoes, Iusatsu-siniranesan (catalogue-number: 8.3-12; coordinates: $36^{\circ} 3$ \% $^{\prime} \mathrm{N}, 138^{\circ} 33^{\prime} \mathrm{E}$ ) and Asama-yama (8.3-11; 36.24' $N$, 138032' E), respectively, showed absolutely no signs of activity during the time of the IIatsushiro surm.

All the historically known eruptions of Kusatsu-Shiranesan were of phreatic character and steam-explosions took place from the central crater (Kuno, 1962) $\left(^{7}\right)$. As the eruptions of this volcano were not true magmatic ones, therefore Kusatsu-Shiranesan is of no interest from our point of view. The inativity of Asama-yama is more important. In other times, namely, this volcano erupter extremely frequently. For instance, the number of known outbursts between 1933 and 1960 was almost two thousands (Kuno, 1962) ( ${ }^{\top}$ ). (haracteristical crustal deformations of the order of \pm 10 centimeter or even higher were observed many times in association with the activity.

In the precent century the inactive periods of Asama-yama were as follows: 
1920: one year. 1923-26: four years. 1933-34: two years. 1943: one year. 1946: one year. 1948: one year. 1956-57: two years. 1960: one vear.

As regards the period between 1961 and 197-1, in Oetober 1961 explosions occurred 1.1 times and in November 40 times. After these events a long pausa followed until the 23ril May, 1965, when wakk explosions and small ash-falls took place. Between the occurrence of this insignificantly minor "eruption" and the really strong explosive outburst on the 1st February, 1973, the volcano had been in a perfectly calm period again. Disregarding now the events on the 23rd May, 1965, as a matter of fact the inactive period has lasted more than 11 years, which, as far as Asama-yama is concerned, is an umusually long period of quietness. It must be emplasized very strongly, furthermore, that the Matsushiro swarm occurred during the period of perfect inactivity of Asama-yama.

\section{2. - THE VERTICAI MODEL.}

In this and the next paragraph the writer expands two ideas by which the explanation of the geophysical phenomena, summarized above, can be given. These are, of course, worling-hypotheses only and at present not too much evidences are at our disposal in favour of the two models which will be discussed in the followings. These two models will be called vertical model and horizontal one, respoctively. We shall point out some of the diffienlties which are still not fully understood, hoping that these unsolved problems will perlans stimulate other authors to a more detailed investigation of the interesting Matsushiro-events, the real canses of which, in spite of the nany investigations carried out up to the present, are not clearly known as yet. The writer feels, lowever, that his two models are physianlly real and acceptable and can be used for the explanation of all the observed facts.

As it was mentioned earlier the base of the new morlels is the inactivity of Asama-yama during the period of the Matsushiro swarm. By some reason the rock-melts could not reach the surfase of the barth through the volcanic conduit and the (top) crater of Asama-yama, but followed another way and moved towards the base of the extinct voleano, Minaliami-yama, very near the town of Matsushiro. 


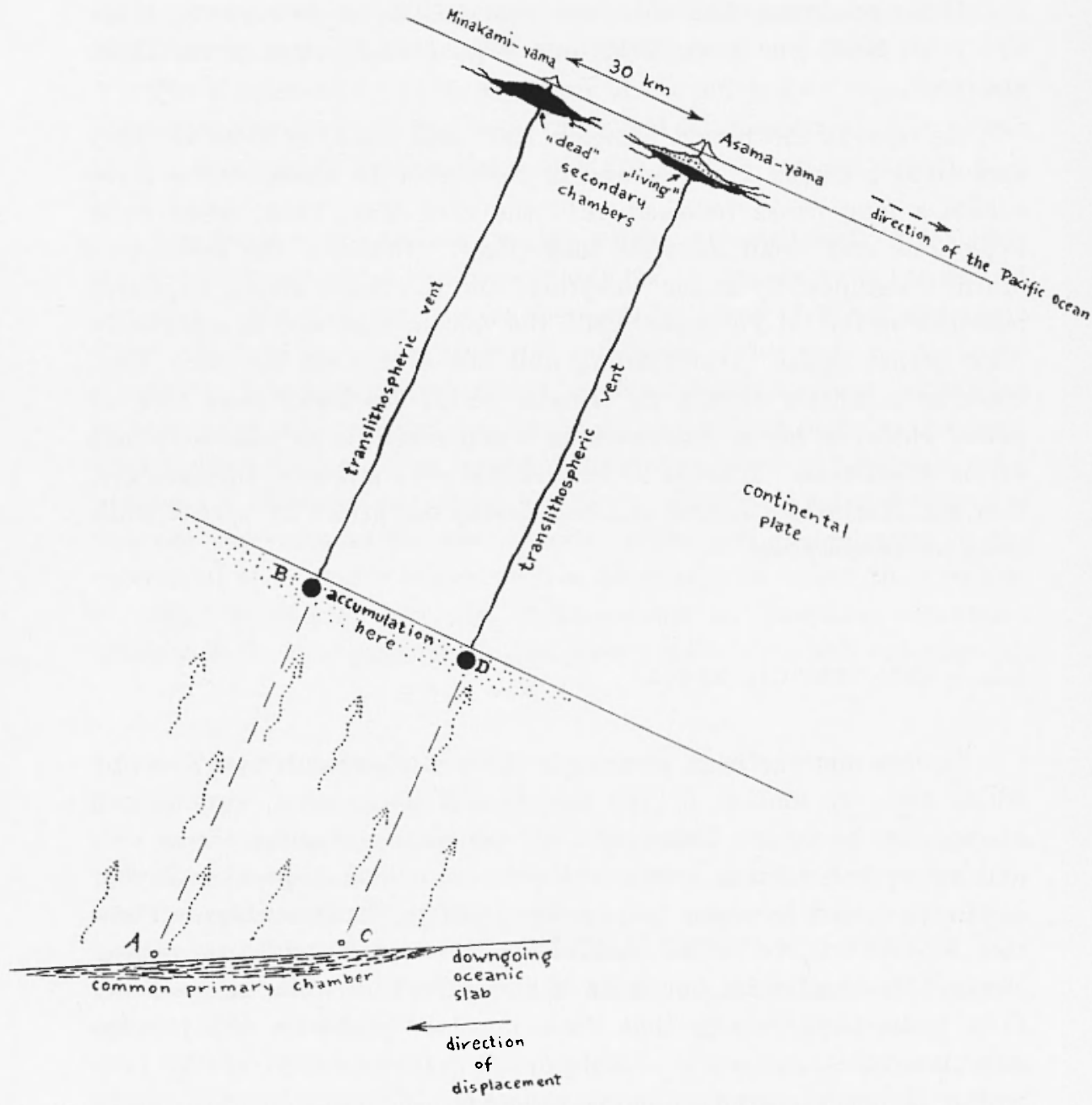

Fig. 2. - The vertical molel. For explanation see the text

The subvolcanic structure might be conceived as represen ted by the above picture (Fig. 2).

At a certain depth, by all likelihood and usually greater than $100 \mathrm{~km}$, there is the source of fresh (acidic and transitional) magma. This domain of magma-generation, called primary magma chamber, belonging to island ares and similar structures, can be found either within the downgoing oceanic lithospheric plate, that is in the interior 
of it (Hatherton-Dickinson model), or along the upper surface of the slab (Toksoz-Minear-Julian-morlel). From this domain the new magma can reach the secondary magma chamber (lying at a very shallow depth just beneath the volcano) through a more or less vertically situater, long conduit, called transtithospheric volcanic vont.

According to the author's vertical morlel, the extinct volcano, Minakami-yama has its own, dead secontary chamber from which its translithospheric vent passes downward. The volcano Asama-yama has a living secondary chamber and also has its own translithospheric vent, as one can see on the enclosed sketch (Fig. 2). It can be supposed, furthermore, that although these vents are separater from one another, they reach the same, common primary chamber, developed in the downgoing lithospheric slab's interior or along its upper surface. As the chamber is connected to the downgoing slab which has an oblique position, the chamber itself has also a similar situation, i.e. it is somewhat obliquely orienterl. The rlistance between the two volcanoes, measurerl along the surface is only some $30 \mathrm{~km}$. In spite of this small distance, the vent of Minakami-yama reaches the common primary chamber at a somewhat greater depth, than that of the Asama-yama, since the latter volcano is being situated nearer to the Pacific Ocean and the oceanic lithospheric slab begins to under thrust along the Great Japanese Trench.

Let us now suppose that the translithospheric vent of Asama-yama had been blocked for a certain time by an enormous mass of solirlified rock-melt. Therefore the gases, originated in the primary chamber, could not transfer the new magma through this conduit towards the surface and thus the secondary chamber of Asama-yama did not receive fresh, new magma. Its magma-supply was more or less exhausted by the two thousands eruptions between 1933 and November, 1961. Therefore from November, 1961, an inactive period started and it lasted until the 1st February, 1973. On this day or some days or weaks earlier the accumulated gases broke through the solidified obstacle (volcanic $p l u g$ ) within the translithospheric vent, and/or the fresh, new magma melted this plug, leading by this process to the occurrence of a new, very strong explosive eruption. Until this event happened, only a relatively few, active magma had been storer within the secondary chamber of Asama-yama and its inherent energy was not enough to produce an eruption on a larger scale. As we know during the long inactive perior only a minor outburst took place (on May 23, 1965, precerling some weeks the beginning of the Matsushiro earthquake swarm). 
In the period, during which the translithospheric volsanic vent of Asama-yama was closed by the solidified magmatic mass, new magma had been created within the common primary chamber of Asama-yama and IInakami-yama. Since the conduit was blocked towards Asamayama, the accumulated gases and the new magma were fored to move through an other way towards the surface.

When the translithospheric vent of Asama-yama was not closed by the plux, this vent offered a free way upward for the new magma and gases. In the absence of such an obstacle within the conduit, no musual acemmulation of magma and gases oceurred along the lower bounlary, of the continental lithospheric plate, that is just above the primary magma chamber. But in the presence of such a plug within the Asama-yama's translithospheric rent, there was only one way for the fresh magma and gases to move upward, namely the old and evidently also closed translithospherie vent of Minakami-yama.

Sow the following problem arises: how could break through the new magma and the gases this solidified, old volamic material which had been stored within the vent of Minakami-yama?

We must talie into consicleration the fact that those parts of the magma and gases which accumulated aromnd point B (see in Fig. 2) came into being at point $\Lambda$; while the magma and gases accumulated around point D, originated at and came from point C. But, as the primary magma chamber las an oblique position, $\mathbf{A}$ is lying at a reeper level than C. Therefore at point $\mathbf{A}$ the temperature and pressure is remarkably higler than at $C$. As a result the thermal energy of the accumulated magmatic mass at point $B$ is greater than that of the magma stored transitionally around point D. Similarly, the accumulated gases have a greater pressure and a higher inherent energy near point $B$ than at $D$.

The aceumulation began just after the closing of the translithospheric vent of Asama-yama, that is somewhat after the last eruption of this roloano (November of 1961). The earthquale-swarm, on the other haml, has begrun as late as August of 1965. Consequently there was enough time - several years - for the accumulation of very hot gases and magma near B and for the acemmlations of remarkably less hot gases and magma at D. As a result the opening of the two translithospheric vents, partly by melting and partly by bursting through the material within the conduits conldn't happen simultaneonsly. It happened earliev in Minaliami-yama's vent because of the greater inherent energy of magma and gases. That is the fresh magma began 
to rise from the lower elge of the eontinental lithosplese towarls the surface at first in Minakami-yama's conduit, ansing the unprecedented carthquake-swarm and other geophysical phenomena near the surface, and during this time the Asama-yama was in an inactive stage. This model is supported by the obsercational fact according to which the hypocentral depth of the voleanic shocks near Minaliami-yama decerased steadily as the time elapsed, showing clearly the effect of an emerging magmatio mass rithin the conduit. Is the Japanese experts have pointed out on the basis of the observations on the spot, the earthquake-swarm was the direct consequence first of all of the microfracturing of the rockis, lying at a shallow depth. This microfmaturing was the result of heating, due to the emerging magma.

\section{3. - THE HORIZONTAL MODEL.}

In this molel the basic supposition is that the shallow combit of Asama-yama was temporarily blocked by a consolidated, solid plug, somewhere between the top-crater and the secondary magma chamber. Therefore the fresh magma could not reach the erater. The secombary chamber, however, was tapped and the rock-melt, previonsly stored in this domain, moved sidenards through a subterrain outlet of the chamber. This outlet might be a more or less horizontally situated dikelike intrusion along a shear-fault. "Iseft-lateral shear-faults ane common in northern Honshu so that there might be a connection between Asama-yama and Minakami-yama which might have been active allealy in the past when the latter voleano came into beinge" (van liemmelen, personal communication).

If one take into consideration the fact that the distance between the eficentral area of the swarm and the top of Asama-yama is as low as $30 \mathrm{~km}$, such a subterrain, direct connection between this volcano and the swan-region seems to be possible. Under the point entitled "IDiscussion" (see at the end of this paper) we shall mention observational facts regarding the possibility of subterain comnections between neighbouring voleanoes. In addition to these the writer wishes to mention some data concerning the probable dimensions of secondary magna. chamber's as well.

According to certain ealculations made by Machado, 1965) (8) and Dachado $1965-1966\left({ }^{\circ}\right)$, respectively, the total length of the secondary magna chamber of Etna nay be about $100-120 \mathrm{~km}$ and its wiolth is 
some $40 \mathrm{~km}$. Under volcano Agua-de-Pau (Azores) a width of $20 \mathrm{~km}$ and a total length of some $60 \mathrm{~km}$ were found.

Taking now into account these figures it seems that $30 \mathrm{~km}$ is not a too great distance; that is a part of the subvoleanic system, existing beneath Asama-yama, ean extend to a domain which is lying just under the extinct voleano Minakami-yama (Fig. 3). A subterrain outlet being $45 \mathrm{~km}$ long"will be mentioned in the "Discussion".

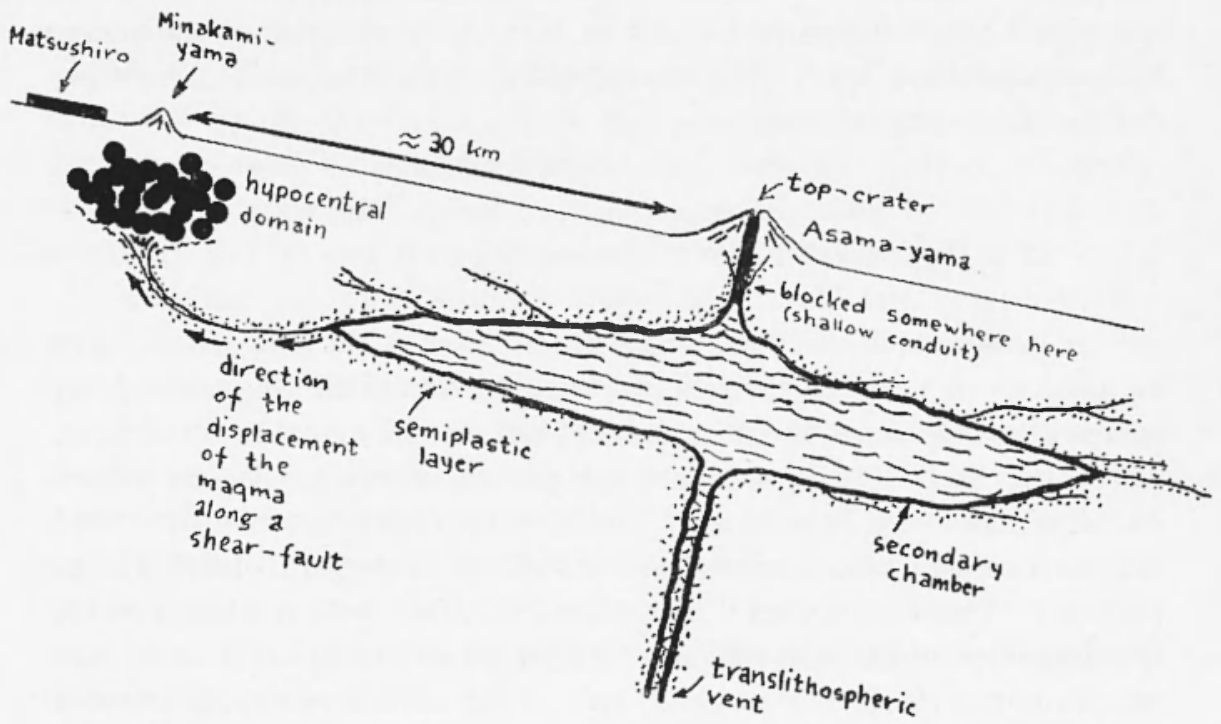

Fig. 3. - The horizontal morlel. For explanation see the text

It may be noted that aceording to the opinion of many experts, the secondary magma chambers begin at a depth of $3-6 \mathrm{~km}$ only, but their thickness (extension towards the interior of the Earth) is not known. Furthermore, it is reasonable to assume that the secondary chambers are surrounded by a peenliar region also of mnknown thickness, in which the rocks are in a semiplastic conclition due to the heat of the nearby magma. In this semiplastic layer of the near the enviromment of the secondary chamber, the material is not hard and rigid enough for the accumulation of mechanical stresses.

This region therefore is free from tectonic earthquakes. Microfracturing, due to heating, can occur only outside of this semiplastic region. 
The subterrain situation may be represented in Fig. 3. Let us suppose now that the shallow conduit (that connects the secondary chamber with the top-crater of Asama-yama) was blocked sonewhere as it is indicated on the rlrawing. Therefore an inactive perior of Asama-yama harl to start. Now the magma began to move slowly towards the base of Minakami-yama along one of the left-lateral shear-faults (or through more than one faults as it is indicated in our figure. This displacement happened more or less parallel to the surface of the Earth. The depth may be about $8-9 \mathrm{~km}$ under the surface, that is somewhat beneath the hypocentral domain developed uncler the Minakami-yama volcano (see later).

Here is an important problem. Why has shifted the magma at this depth along a fault instead of breaking through the plug in the shallow conduit of Asama-yama? A possible answer to this question may be that in the latter case the magma had to work against gravity and harl to work against the internal strength of the rocks of the plug, simultaneously. But in the case of a sideward displacement (more or less parallel with the surface of the local geoid) no work was needed against the gravity. Furthermore: if the secondary chamber of Asamayama is long enough, in this case the way through the fault (see on the drawing) is relatively short.

Another problem is as follows: the period of dormancy of Asamayama was much longer than the duration of the Matsushiro-swarm as a whole. Why? The answer is self-evident and easy. The reason is, namely, that a certain time was needed for the magma to find its possible way sidewards, that is towards beneath the base of Minakamiyama. But as we shall see later, too, this magma never reached the surface. And - on the other hand - a certain time was needed within the secondary chamber of Asama-yama until a remarkable amount of gases accumulater which was necessary to break through the plug in the shallow conduit. As we know, this happened only some days or weaks precerling the powerful explosive eruption of Asama-yama on the 1st February, 1973.

If our hypothesis on the possibility of the lateral displacement of magma holds, that is the horizontal model is acceptable, than one can expect, especially if the beginning perion of seismic activity is concerned, that a slow migration of the equcentral area had to occur. Similarly, as the time elapsed, a slight displacement of the hypocenters 10wards the surface is also to be expected. Really, we have some evidences that such shifts did occur, and these are in favour of the hypothesis. 
Hagiwara and I wata (1968) $\left({ }^{2}\right)$ pointed out that in the very first stage of the seismic activity small earthquakes were observed only at the southwestern slope of Minakami-yama in August and September, 1965, while within the Walhako Prefecture, north of Minakami-rama, no earthqualies occurred at this time (Fig. 4, and Fig. 5). In October

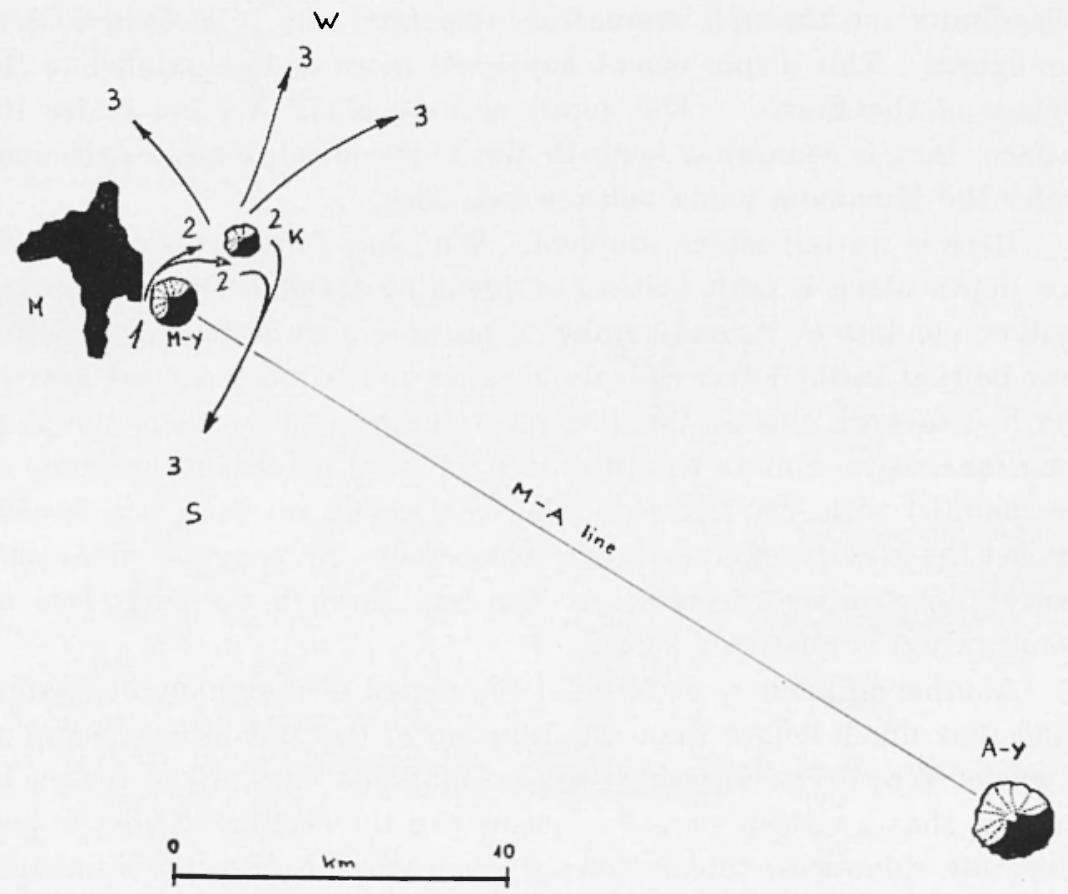

Fig. 4. - Migration of seismic activity. 1) August and September, 1965; 2) October, 1965; 3) March-July and August-September, 1966. M $=$ Matsushiro; $\mathrm{H}-\mathrm{y}=$ Minakami-yama; $\mathrm{K}=$ Kimyosan; $\mathrm{A}-\mathrm{y}=$ Asama-yama; $W=$ Wahako district: $S=$ Sanala distriet (After the data of llagiwara and lwata, $1968\left({ }^{2}\right)$, eompiled by the anthor).

small earthquakes took place around Kimyosan (Nount Kimyo), at about $3 \mathrm{~km}$ northeast of Minakami-yama. Kimyosan is situated farther from that line which comnects Asama-yama with Matsushiro, than Minakami-yama itself. Hamakla and Magiwara (1966) (3) also noted a westward drift of epicentres during the next year, more precisely speaking in August and September, 1966, and a northeastward one is also known from March-July, 1966. Generally, it can be stated that the center of activity was lying at first just on the Matsushiro - 
Asama-yama line near and under Minakami-yama and later on the activity spreal from this area towards the neighbouring regions, as it is indicater in Fig. 4. This migration is consistent with the idlea that the shocks reflected the distribution and displacement of magma that
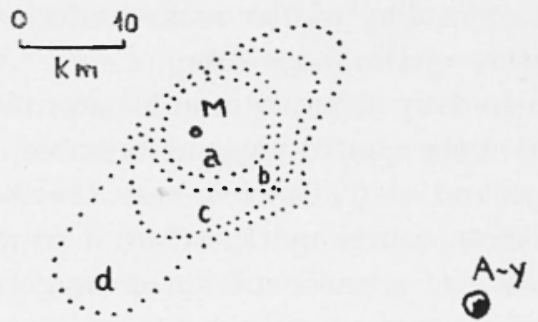

Fig. 5. - Areal distribution of seismicity between Aurust, 1965, and Octoher, 1967 (on the hasis of data provided by llagiwara and lwata $\left(^{2}\right)$ ). $\mathrm{M}=$ Matsushiro; $\lambda-y=$ Asama-yama; a) August, 1965 - February, 1966; b) Ifareh, 1966 - July 1966; (c) August, 1966 - December 1966, d) January, 1967 - October. 1967.

arrived from the secondary chamber of Asama-yama. As it was mentioned previously the earthquakes were due first of all to microfraceturing in the orustal rocks. Therefore the first shocks oceurred not just along the border of the magma chamber, as the rocks there are in a semiplastic condition, but farther, where the rooks were rigirl enough to permit the occurrence of microfracturing within themselves. It is noteworthy, moreover, that according to Hamada and Hagiwara (1966) (3) the hypocentral depths decreased after the ent of July, 1966, and this decrease got even more expressed in the mirldle of October, the same year (Hamala and Hagiwara, 1967) ('). These observations on the decreasing tendency of the focal depths are cilso in excellent accord with the expectations, bused on the horizontal model, as they supporterl at the same time the vertical model as well.

\section{2. - CONCIJUING REMIRK'S}

The opinions on the true nature and cause of the Matsushiro-events are not unanimous. For instance, in their first paper on the swarm, Rikitake and his eo-workers (1966) ${ }^{(19)}$ pointed out that certain changes in the local geomagnetic field were observed at the epicentral 
region. Similar variations in the magnetic inclination were experienced at volcano Mihara-yama, during its eruption in the years of 1950 and 1951. The phenomenon at Mihara-yama might have been the result of the demagnetization of the rocks, due to the rise of their temperature and - respectively - due to their new magnetization (remagnetization) during the period of cooling of the rocks uncler consideration below the Curie-temperature of the magnetite.

It was emphasized by Rikitake and his co-workers $\left({ }^{13}\right)$ that up to the time of writing of the quoter paper (December, 1965) only a slight upheaval of the ground was observerl near the town of Matsushiro, at the foot of Minakami-yama and therefore it seemed as though only the dike-like intrusion of a small amount of magma would have been responsible for the creation of the events at Matsushiro, but not a larger volume of rock-melts was involver. Bnt now having a knowledge of the results of geodetic measurements, carried out later, that is during the further progress of the swarm and other events, we are able to state that crustal deformations on a much larger scale had taken place. Hence, on this basis, the intrusion of a more voluminous magma seems to be very liliely. We can estimate it on an energetical base, as follows:

The number of earthquakes of higher magnitudes in the Matsushiro-area from October 1965 to October 1967 was the following (Hagiwara and Iwata, 1968) $\left({ }^{2}\right)$ :

$$
\begin{array}{cccc}
M \sim 3.9 & M=4.0-4.9 & M \geqslant 5.0 & \text { Total } \\
7664 & 388 & 9 & 8061
\end{array}
$$

The total seismic energy released by these 8061 shocks amounts to $1.66 \cdot 10^{21}$ ergs. On the other hand (Kasahara, 1970) (6) for the creation of crustal deformations about $17 \cdot 10^{21}$ ergs energy was used $\left(7 \cdot 10^{21}\right.$ ergs for local and $10 \cdot 10^{21}$ ergs for regional crustal deformations). IIence, the total energy necessary to produce the earthquakes and crustal deformations together amounts to $1.866 \cdot 10^{2}$ ergs. If we take into consideration the medium density of magma as $3.0 \mathrm{gr} \mathrm{cm}^{-3}$ and its temperature as $1000^{\circ} \mathrm{C}$, we got the result that this value corresponds to the total thermal energy of a magmatic mass with a volume of roughly 500,000 eubie metres. This is a lather remarkable volume, however the whole volume of magma, playing a role in the Matsushiroevents was certainly higher since only a fraction of its inherent energy was used for the reation of the phenomena.

In spite of the larger contortion of the ground, that commeneed later (i.e. after the writing of the quoted paper, December 1965), Riki- 
take and his co-workers have preferred the idea according to which the local anomalous change in the geomagnetic field was attributable to a piezo-magnetic effect (Rikitake et al., 1966, 1967) (13), that is not to the intrusion of a hot magmatic mass. Iasahara (1970) (6) had a similar view.

Here we can mention that some kind of changes in the gravity field were also observed. This support the idea according to which a dense material - probably magma - had penetrated into the rocks beneath Minakami-yama and its environment. The changes in the local geomagnetic and gravity fields can - accor dingly - be attributed to the same phenomenon. The view concerning the piezo-magnetic effect can not explain the change in the gravity field, but only that of the magnetic one. Similarly by the supposition of a piezo-magnetic effect we can not account for the crustal deformations and the outpouring of ground-water.

Morimoto and his co-workers are of the opinion (Morimoto et al., 1966) (12) that "From the geological point of view, both volcanism and tectonic movements are probable as the cause of the present earthqualies" (op. cit., p. 444). "But it is improbable at least that there exists a large shallow magma reservoir of several hundred metres or more in diameter or a growing dike swarm in hypocentral area at a depth of several kilometres beneath the surface. Therefore, if the magma should play an important role in bringing about the present earthquakes, the head of magma should be deeper than the focal realm ... (Italies mine - P. H.). A fracture system of $E W$ direction is supported in the basement rocks beneath the hypocentral realm. A magma from a deeper source had intruded upuards enlarging these features, resulting in extension of the overlying part of the crust towards NS-direction" ( $p .4+5)$.

Hagiwara, $1966\left({ }^{1}\right)$, has also suggested that if an active magma existed and penetrated into beneath the territory of the seismic events, the head of this magmatic mass should be rather deep.

It is evilent that the magma from first to last has remained underneath the hypocentral domain and thus never reached the surface.

From this point of view the Matsushiro-swarm as a whole reminds very much to the case of the similarly famous Ito earthquake-swarm that occurred on the Izu - peninsula in the year of 1930. The shocks at Ito were distributed between the depth of 2 and $i \mathrm{~km}$ with a strong concentration between 5 and $6 \mathrm{~km}$. In this respect the author wish to refer to some sentences, written by Minakami, $1960\left({ }^{10}\right)$.

"Man! investigators incline to regard the Ito earthqualie swarm as a lind of igneous activity in which magma under the ground intruded to a 
esitain depth of the earth's crust. They regard the Ito earthqualie swarm as an intermediate phenomenon between general earthqualie phenomena and volearic phenomena. If the magma had asconded furthor, the magma would have been ertruded and would have formed a voleano such as syouraSinzan or Parioutin".

The present writer is convincel that almost the same event oocurred at Iatsushiro during the unique earthquake swarm. By the supposition of a magma intrusion we can explain all of the phenomena olserved on the spot. These are summarized in Table 1

TABLE 1

\begin{tabular}{|c|c|}
\hline Even'l' & CAUSE \\
\hline Earthquakes & $\begin{array}{l}\text { Vierofracturing above the head of the emerg- } \\
\text { ing (uygoing) magmal }\end{array}$ \\
\hline $\begin{array}{l}\text { Changes in the local } \\
\text { geomagnetic field }\end{array}$ & $\begin{array}{l}\text { Demagnetization of the rocks heated by the } \\
\text { upgoing magma, and remagnetization during } \\
\text { their cooling process }\end{array}$ \\
\hline $\begin{array}{l}\text { Changes in the local } \\
\text { gravity field }\end{array}$ & $\begin{array}{l}\text { Intrusion of dense material (magma) into the } \\
\text { crustal rocks which have a lower density }\end{array}$ \\
\hline $\begin{array}{l}\text { Deformations of the } \\
\text { ground especially at } \\
\text { Irinakimi-yama }\end{array}$ & $\begin{array}{l}\text { Intrusion of magma, similarly to the casse of } \\
\text { Syowa-Sinzan volcano in } 1943 \text {, although at } \\
\text { Matsushiro the magma never reached the } \\
\text { free surface }\end{array}$ \\
\hline $\begin{array}{l}\text { Inactivity of } \Lambda \text { sama- } \\
\text { yama voleano }\end{array}$ & $\begin{array}{l}\text { During a certain period of time, Asama-yama } \\
\text { did not receive fresh magma, but the magma } \\
\text { moved towards the base of Minakami-yama } \\
\text { as expressed in this palper }\end{array}$ \\
\hline $\begin{array}{l}\text { Appearance of a great } \\
\text { amomt of ground-water } \\
\text { on the surface }\end{array}$ & $\begin{array}{l}\text { The ground-water was squeezed out by the } \\
\text { emerging mass of magna }\end{array}$ \\
\hline $\begin{array}{l}\text { Iandlides and fracturing } \\
\text { of the gromel }\end{array}$ & $\begin{array}{l}\text { These phemomena were evidently connected } \\
\text { to the gromud-deformations and the many } \\
\text { eartheluakes }\end{array}$ \\
\hline
\end{tabular}




\section{3. - DISCUSSION}

Professor R. W. van Bemmelen (Den Haag, Holland):

The statistical relation between the Matsushiro earthquake swarm and the quietness (dormancy) of Asama-yama is a remarkable basic observation. The interpretation might be either a direct relation at shallow level between the subrolcanic chamber of Asama-yama and the extinct volcano Minakami-yama, or a deeper relation beneath the erystalline basement complex (say perhaps under the comad discontimuity) where deep seated faults (shear-fanlts) allow release of stresses along sidewards stress gradients.

Dr. P. Hedervári: I think that my so called vertical model conesponds to the second possibility, mentioned by Professor van Bemmelen.

Dr. J. H. Latter (Wellington, New Zealand): Your comments on the Matsushiro swarm and the inactivity of Asama sound very convincing. I have not heard this suggestion made before.

Dr. P. Hederciri: Dr. Latter's words refer to the so called horizontal model. The essence of this model is the supposition according to which subterrain connections between neighbouring volcanoes ase possible. In our present case the volcanoes in question are Asama-yama and Minakami-yama, respectively, although the latter is considered to be extinct since one or more huncled thousands of years. Regarding the possible existence of such subterrain relations I wish to refer to two volcanoes. The first belongs to the category of those volsanoes the magma of which is basaltic, poor in gases and has a relatively low viscosity. Its explosive inclex is generally low except some rare cases of phreatic eruptions. The second example - on the contrary - has a magma of rhyolitic composition which is very rich in gases and has a relatively high viscosity. Its explosive index is very high. Thus we have to do with two extreme cases. Asama-yama, which has a Voleanian character with medium gas-content and a medium viscosity, is placed at about half-way between these two extremities.

The first case is the combined Kilauea Iki - Kapoho eruption in Hawaii. According to the Atlas of Voleanic Phenomena (U. S. Geological Survey, authors are J. P. Eaton and R. G. Schmidt, respectively, Sheet 19):

"The most spectacular eruption of Kilauea Volcano in modern times started at the satellitic erater of Kilauea Iki (Little Kilauna), lying just outside the main caldera, in late 1959. The eruption occurred in 3 stages: 
1st Stage - Summit eruption at Kilauea Ili. In early October 1959, earthquakes at Kilauea Caldera multiplied as the entive summit region swelled in response to rising magma. At 8:00 p.m., November 14, lava fountains erupted from a rift 1,200 feet long on the south wall of Kilauea Iki, and cascades of lava poured into the crater. On the following day the euption narrowed to a single strong fountain at the west end of the crater. This stage continued intermittently until December 21.

2nd Stage - Flank eruption at Kapoho. Following the eruption at Kilauea Ihi, seismic tremors continued as subterranean lava moved outwarl beneath the east rift zone. On January 13, 1960, a flank eruption occurred from a fissure half a mile long on the east rift zone near Kapoho Village, about 28 miles (some $45 \mathrm{~km}-$ P. II.) east of the summit caldera. The eruption soon became restricted to a single powerful fountain that at times attained a height of 1,400 feet or more. Lava from this vent poured eastward to the ocean, forming a fan-shaped flow that covered an area of about 4 square miles. This stage of the eruption ended on February 19, 1960.

3rd Stage - Collapse of Halemaumau crater. Four days after the start of the Kapoho eruption, the summit of Kilauea began to sink as lava drained from beneath the caldera and moved into the east rift zone. On February 7 the entire floor of Halemaumau settled about 150 feet, and a small circular area in the center dropped another 200 feet. Two additional secondary pits were formed by local collapse - one on February 9, the other on Mareh 11 - to end the eruption. (Italies mine P. H.).

In the summary of a paper, written by $\mathrm{P}$. Bordet, G. Marinelli, M. Mittempergher and H. Tazieff, respectively (Contribution a l'étude Volcanologique du Katmai, etc., Mémoires de la Soc. Belg. de Géol, Série in-8 ${ }^{\circ}$, No. 7,1963 ) we can read the following important statement:

The June 1962 activity consisted, first in a strong subcrater-lake fumarolic activity in the Katmai caldera and a powerful gasblast activity on the cumulo-dome of Mt. Trident; it was followed by a violent and short explosive eruption at the Trident dome, and by a dead stop of the Katmai fumarolic activity; it looks to the authors as a confirmation that, remembering the 1912 Katmai - Nova Rupta concomitant eruptions, underground connections do exist under the Katmai District volcanoes. These connections could be regional tectonic faults, the working of which may, as in 1912, exactly precede, or accompany, the eruption. These characteristics are very exceptional indeed, and should deserve a thorough feld analysis, both volcano-tectonical and scismological". (Italies mine - P. H.) 
Concerning the Katmai-event, of 1912 we may add, after P. Is. Ward and T. Matumoto (A Summary of Volcanic and Seismic Activity in Katmai National Monument, Alaska; Bull. Volc., 31, 1967, p. 12), that: ". . the majority of the activity came from Novarupta, a crater $10 \mathrm{~km}$ west of Mt. Katmai... It is through that after this (volcanic - P. H.) material had been drained out through or near Novarupta, but from under Mt. Katmai, Katmai's summit collapsed"'. (Italics mine - P. H.)

Taking now into consideration these interesting observations we can really suppose that subterrain connections between neighbouring volcanoes (by the presence of 10-45 kilometres long, regional tectonic faults within the uppermost 10-15 kilometres of the solid crust) may be possible, perhaps in the case of whatever volcanoes, that is independently from the type (character) of activity. By other words the observations concerning the Kilauea Iki - Kapoho event on one hand and the Katmai - Nova Rupta - Mrt. Trident events on the other are in favour of my horizontal model.

\section{APPENDIX}

According to the results of recent investigations, carried out by the author (see: RGPGV Report No. 6, August, 1976) the Matsushiro earthquake swarm was preceded by three intermediate, furthermore one deep and one shallow shocks, all took place in 1965 near the area considered (data are given originally in J. P. Rothe: The Seismicity of the Earth, 1953-1965, Paris, 1969). The data of the shallow shock are: $1965.04 .19 ., 34.9^{\circ} \mathrm{N}, 138.0^{\circ} \mathrm{E}, h=50 \mathrm{~km}, M=6.3$. That is this was a rather powerful earthquake, that occurred at only $220 \mathrm{~km}$ southwest of Asama-yama. By all likelihood this shock might have had a triggering role which caused the commencement of the movement of the magma from the secondary chamber of Asama-yama through the subterrain fault or fissure towards and under Minakami-yama, just near Matsushiro, corresponding to the so called horizontal morlel. In RGPGV Report No. 6. some further examples are treated when tectonic earthquakes of shallow origin triggered volcanic eruptions in the near proximity of the epicenter. 


\section{ACKNOWLEDGMENT}

The author is very obliged to $\mathrm{Mr}$. G. Totlı (Burlapest) for his kind help in preparing this paper and for his valuable comments and advises.

\section{REFERENCES}

(') Hagiwara, Y., 1966. - Natural Radioactivity in the Matsushiro Earthquake Area. "Bull. Earthq. Res. Inst." "BERI"), 44, 3.

(2) Hagwara, 'T., I WaTA, T., 1968. - Summary of Seismographic Observation of Matsushiro Swarm Earthquakes. "BERI", 46, 3.

(3) IIAMAdA, K., HaGiwara, T., 1966. - Migh. Sensitivily Triparite Observation at Matsushiro Earthquakes. Part 3., "BERI", 44, 4.

(4) II Amada, K. - Hagiwara, T., 1967. - High Sensitivit! Triparile Observation at Matsushiro Eacthquales, Part 4. "BERI", 45, 1.

$\left(^{5}\right)$ Kasainara, K. et al., 1968. - Electro-Optical Measurements of Horizontal Strains Accumulating in the Surm Earthquake Area-Part 4. "BERI", 46, 3 .

(6) Kasainara, K., 1970. - The Source Region of the Matsushiro Swarm Earthquakes. "BERI", 48, 4.

(7) Kuxo, H., 1962. - Calalogue of the Active Folcanoes of the IVorld. Part $X I$ :Japan, Taiwan and Marianas. Napoli.

(8) MaCnano, F., 1965. - The Messina Earthquake of 1908 and the Magma Chamber of Etha. "Bulletin Tolcanologique", 28.

(9) Machado, F. 1965-1966. - Anomalias das Intensidades do Terramoto de S. Miguel (.I cores) em. 1.522. Boletim do Musen e Laboratorio Mineralogico. . , 10, 2.

$\left.{ }^{10}\right)$ Minakami, 'T., 1960. - Fundamenlal Research for Predicting Voleanic Eruptions - Part 1. "BERI", 38, p1. 497-544.

(11) Mogr, K., 1958. - Relations between the Eruptions of Various Toleanoes and the Deformation of the Ground surface around them. "BERI", 36, pp. 99-134.

(12) Morimoto, R, et al., 1966. - Geological Gonsideration on the Matsushiro Earthquake Swarm since 1965 in Central Japan. "BERI", 44, 1.

(13) Rikitrake, T. et al., 1966-1967. - Geomagnetic and Geoelectric Studies of the Matsushiro Earthquale Swarm - Part I. "BERI", 44, I. Part 4. "BERI", 44, 4. Part. 5. "BERI", 45, 2. 